\title{
Kelainan refraksi pada pelajar SMA Negeri 7 Manado
}

\author{
${ }^{1}$ Angelia V. Adile \\ ${ }^{2}$ Yamin Tongku \\ ${ }^{2}$ Laya M. Rares
}

\author{
${ }^{1}$ Kandidat Skripsi Fakultas Kedokteran Universitas Sam Ratulangi Manado \\ ${ }^{2}$ Bagian Ilmu Kesehatan Mata Fakultas Kedokteran Universitas Sam Ratulangi Manado \\ Email: angelsvie811@gmail.com
}

\begin{abstract}
The incidence of uncorrected refractive errors is high in school-age children. If this condition is not treated seriously, it will have a negative impact on the development of children's intelligence and learning process which in turn will affect the quality, creativity, and productivity of work. This study was aimed to determine the refractive errors in students at SMA Negeri 7 (Senior High School) Manado. This study used a cross sectional design and was conducted from November to December 2015. Respondents were 25 students at grades 12th of SMA Negeri 7 Manado who had refractive errors obtained by using total sampling method. Visual acuity was assessed by using Snellen chart. The results showed that of all respondents, $72 \%$ were females and $28 \%$ were males. Based on the types of refractive errors, $72 \%$ had myopia and 28\% had myopia associated with astigmatism. Most of the subjects $(52 \%)$ were 17 years old. As many as $64 \%$ of respondents had family history of refractive errors. Respondents who performed near-sight activity were $96 \%$; most of the activities was watching the television.
\end{abstract}

Keywords: refractive error, risk factor, near-sight activity, school-age children

\begin{abstract}
Abstrak: Angka kejadian kelainan refraksi yang tak terkoreksi cukup tinggi pada anak usia sekolah. Jika kondisi ini tidak ditangani sungguh-sungguh akan berdampak negatif pada perkembangan kecerdasan anak dan proses pembelajaran yang selanjutnya akan memengaruhi mutu, kreativitas, dan produktivitas kerja. Penelitian ini bertujuan untuk mengetahui gambaran kelainan refraksi pada pelajar di SMA Negeri 7 Manado. Penelitian ini menggunakan desain potong lintang dan dilaksanakan pada bulan November-Desember 2015. Responden ialah 25 siswa/i kelas XII SMA Negeri 7 Manado yang mengalami kelainan refraksi, diperoleh dengan metode total sampling. Pengambilan data dilakukan dengan pemeriksaan visus menggunakan Snellen chart dan kuesioner. Hasil penelitian mendapatkan dari seluruh responden didapatkan $72 \%$ berjenis kelamin perempuan dan $28 \%$ berjenis kelamin laki-laki. Berdasarkan jenis kelainan refraksi didapatkan $72 \%$ menderita kelainan refraksi miopia. Sebagian besar responden berusia 17 tahun (52\%). Sebanyak 64\% penderita memiliki riwayat keluarga inti dengan kelainan refraksi. Responden yang melakukan aktivitas melihat jarak dekat dan lama sebanyak 96\% dan aktivitas yang paling banyak dilakukan ialah menonton televisi.
\end{abstract}

Kata kunci: kelainan refraksi, faktor resiko, aktivitas melihat jarak dekat, anak usia sekolah

Mata merupakan organ penglihatan yang diciptakan Tuhan dan merupakan salah satu organ vital yang penting nilainya. ${ }^{1}$ Meskipun fungsinya bagi kehidupan manusia sangat penting, sering kali kesehatan mata kurang diperhatikan sehingga banyak penyakit yang menyerang mata tidak diobati dengan baik dan menyebabkan gangguan penglihatan sampai kebutaan. Salah satu gangguan pengelihatan yang sering terjadi ialah kelainan refraksi. ${ }^{2}$ 
Berdasarkan data dari World Health Organization (WHO), di seluruh dunia pada tahun 2010 terdapat sebanyak 285 juta orang $(4,24 \%)$ populasi dengan gangguan penglihatan; 39 juta $(0,58 \%)$ dengan kebutaan; dan 246 juta $(3,65 \%)$ dengan low vision. Penyebab gangguan penglihatan terbanyak di seluruh dunia ialah kelainan refraksi (43\%), katarak (33\%), dan glaukoma (2\%)., ${ }^{3,4}$ Dari data tersebut, diperkirakan saat ini 19 juta anak di bawah usia 15 tahun menderita gangguan penglihatan; 12 juta diantaranya menderita kelainan refraksi yang tidak dikoreksi. $^{4}$

Anak-anak sering tidak menyadari visusnya menurun dan mungkin tidak mengeluh bahkan ketika mereka menderita mata lelah atau kebutaan. ${ }^{5}$ Sekitar $10 \%$ dari 66 juta anak usia sekolah (5-19 tahun) di Indonesia mengalami kelainan refraksi dan angka pemakaian kacamata koreksi sampai saat ini masih rendah yaitu $12,5 \%$ dari kebutuhan. Jika kondisi ini tidak ditangani secara baik akan berdampak negatif pada perkembangan kecerdasan anak dan proses pembelajaran yang selanjutnya akan memengaruhi mutu, kreativitas, dan produktivitas angkatan kerja. ${ }^{6}$

Deteksi dini dan publikasi informasi mengenai angka kejadian kelainan refraksi dan faktor-faktor yang berhubungan pada anak usia sekolah masih jarang dilakukan; hal inilah yang melatar belakangi peneliti untuk membuat penelitian ini.

\section{METODE PENELITIAN}

Jenis penelitian ialah deskriptif dengan desain potong lintang menggunakan kuesioner dan pemeriksaan visus yang dilakukan pada bulan November dan Desember 2015. Lokasi penelitian di SMA Negeri 7 Manado. Responden ialah siswasiswi kelas XII SMA Negeri 7 Manado yang mengalami kelainan refraksi dan memenuhi kriteria inklusi. Pengambilan sampel dilakukan secara total sampling.

Variabel penelitian ialah: usia, jenis kelamin, jenis kelainan refraksi, riwayat keluarga dengan kelainan refraksi, dan aktivitas melihat jarak dekat

\section{HASIL PENELITIAN}

Setelah dilakukan penelitian pada pelajar di SMA Negeri 7 Manado yang mengalami kelainan refraksi melalui pengambilan data primer di lokasi penelitian didapatkan responden sebanyak 25 pelajar. Dalam penelitian ini, prevalensi responden berjenis kelamin perempuan yang mengalami kelainan refraksi lebih banyak dibandingkan laki-laki (Gambar 1).

\section{Jenis kelamin responden}

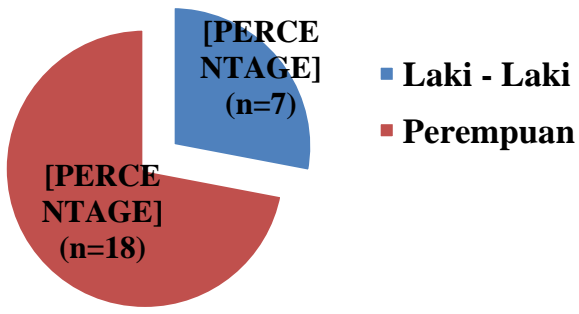

Gambar 1. Distribusi responden berdasarkan jenis kelamin

Tabel 1 memperlihatkan bahwa kelainan refraksi yang terbanyak pada responden ialah miopia. Sebanyak 7 responden (28\%) menderita miopia bersamaan dengan astigmatisme.

Tabel 1. Distribusi responden berdasarkan jenis kelainan refraksi

\begin{tabular}{ccc}
\hline $\begin{array}{c}\text { Jenis kelainan } \\
\text { refraksi }\end{array}$ & $(\mathbf{n})$ & $\mathbf{( \% )}$ \\
\hline Miopia & 18 & 72 \\
Hipermetropia & - & - \\
Astigmatisme & - & - \\
\hline
\end{tabular}

Tabel 2 memperlihatkan bahwa responden terbanyak berusia 17 tahun. Terdapat lebih banyak responden memiliki riwayat keluarga yang mengalami kelainan refraksi (Gambar 2).

Tabel 2. Distribusi responden berdasarkan usia

\begin{tabular}{ccc}
\hline Usia & Jumlah & $\mathbf{( \% )}$ \\
\hline 16 Tahun & 11 & 44 \\
17 Tahun & 13 & 52 \\
18 Tahun & 1 & 4 \\
Total & 25 & 100 \\
\hline
\end{tabular}




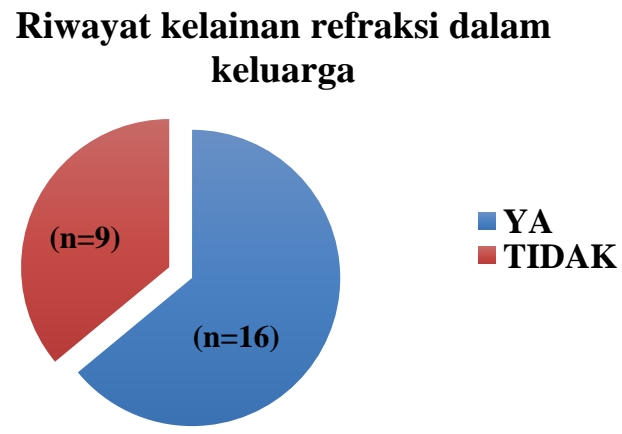

Gambar 2. Distribusi responden berdasarkan riwayat kelainan refraksi dalam keluarga

Tabel 3 menunjukkan bahwa menonton televisi merupakan aktivitas yang paling sering dilakukan responden.

Tabel 3. Distribusi responden berdasarkan jenis aktivitas melihat jarak dekat dan lama yang sering dilakukan

\begin{tabular}{ccccc}
\hline Kegiatan & \multicolumn{2}{c}{ Melakukan } & \multicolumn{2}{c}{ Tidak } \\
& Melakukan \\
\cline { 2 - 5 } & $\mathbf{n}$ & $\mathbf{\%}$ & $\mathbf{n}$ & $\mathbf{\%}$ \\
\hline Membaca & 12 & 48 & 13 & 52 \\
buku & 16 & 64 & 9 & 36 \\
$\begin{array}{c}\text { Menonton } \\
\text { televisi }\end{array}$ & 10 & 40 & 15 & 60 \\
$\begin{array}{c}\text { Menggunakan } \\
\text { komputer } \\
\text { Bermain } \\
\text { game/PS }\end{array}$ & 5 & 20 & 20 & 80 \\
$\begin{array}{c}\text { Menggunakan } \\
\text { handphone }\end{array}$ & 8 & 32 & 32 & 68 \\
\hline
\end{tabular}

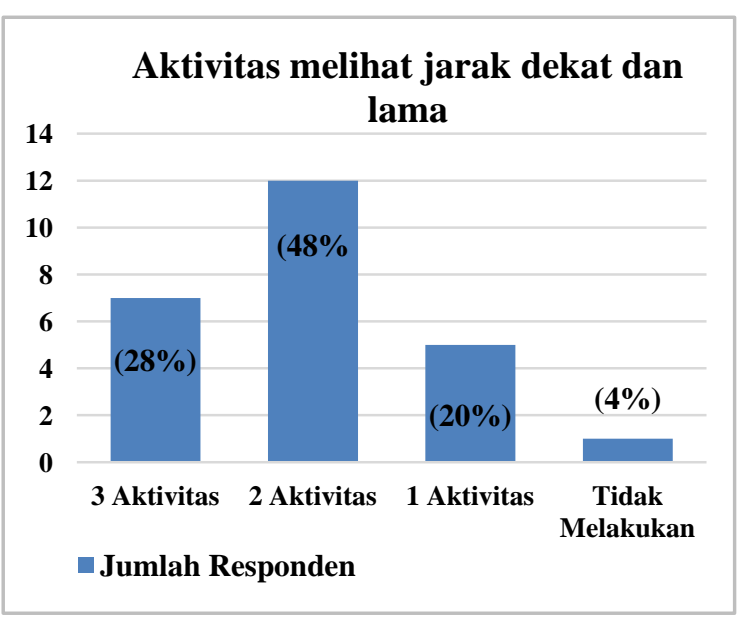

Gambar 3. Distribusi responden berdasarkan jumlah aktivitas melihat jarak dekat dan lama yang sering dilakukan
Pada Gambar 3 dapat dilihat bahwa 96\% responden melakukan aktivitas melihat jarak dekat dan lama; paling banyak melakukan 2 aktivitas.

\section{BAHASAN}

Umumnya hasil penelitian menunjukan persentasi kelainan refraksi miopia yang terbanyak. Persentase miopia tertinggi dibandingkan refraksi anomali lainnya dilaporkan oleh Komariah dan $\mathrm{Wahyu}^{7}$ di Malang 43\%; Czepita et al. ${ }^{8}$ di Polandia $68 \%$; Usman ${ }^{9}$ di Riau ${ }^{9} 56,5 \%$, Joseph et al. ${ }^{10}$ di India 97,9\%, dan Ratanna et $\mathrm{al}^{2}$ di Manado 71,78\%. Sejalan dengan penelitian sebelumnya, pada penelitian ini didapatkan bahwa kelainan refraksi yang paling banyak ditemukan pada pelajar SMA Negeri 7 Manado ialah miopia (72\%).

Pada penelitian ini, untuk karateristik jenis kelamin ditunjukkan paling banyak responden berjenis kelamin perempuan (72\%). Beberapa penelitian sebelumnya juga menunjukan hal yang serupa, 2,8,9 namun ada juga penelitian yang melaporkan hasil yang berbeda seperti penelitian di India $^{10}$ yang mendapatkan laki-laki lebih banyak dibandingkan perempuan yaitu sebanyak $65,9 \%$.

Dari 25 responden pada penelitian didapatkan hasil riwayat keluarga inti yang memakai kacamata sebanyak 16 orang (64\%). Fachrian et al. ${ }^{11}$ menyatakan bahwa tidak ada hubungan bermakna antara keluarga inti yang memakai kacamata (gangguan kelainan refraksi) dengan anak yang juga mengalami kelainan refraksi karena kelainan refraksi lebih banyak dipengaruhi oleh kebiasaan atau gaya hidup anak itu sendiri. Faktor herediter biasanya berpengaruh terhadap kebiasaan anaknya, demikian juga dengan kelainan refraksi. Fakta bahwa orangtua yang suka membaca, akan berbagi budaya dengan mendorong anak-anak mereka untuk membaca juga. ${ }^{12}$

Sebanyak $96 \%$ responden melakukan aktivitas melihat dekat dan lama. Faktor gaya hidup yaitu aktivitas melihat dekat yang terlalu banyak, seperti membaca buku, melihat layar komputer, bermain game/playstation, menonton televisi, dapat 
menyebabkan lemahnya otot siliaris mata sehingga mengakibatkan ganguan otot untuk melihat jauh. Faktor gaya hidup ini didukung tingginya akses terhadap media akivitas visual. ${ }^{1}$

Pada penelitian ini, aktivitas melihat dekat dan lama yang paling banyak dilakukan ialah menonton televisi $(60 \%)$. Tingginya akses terhadap media visual ini bila tidak diimbangi dengan pengawasan waktu dan jarak menonton anak oleh orang tua dapat meningkatkan kelainan tajam penglihatan. $^{11}$ Hal ini sejalan dengan penelitian Imam et al. ${ }^{13}$ di Yogyakarta tentang hubungan aktivitas melihat jarak dekat dengan kejadian miopia yang walaupun tidak menunjukkan perbedaan yang bermakna secara statistik $(p>0,05)$ dari seluruh parameter yang digunakan untuk aktivitas melihat jarak dekat (belajar, menonton televisi, menggunakan komputer dan aktivitas melihat dekat lain) namun kecenderungan bahwa semakin tinggi aktivitas melihat dekat maka akan semakin tinggi pertambahan miopianya.

\section{SIMPULAN}

Berdasarkan hasil penelitian dapat disimpulkan bahwa yang terbanyak ditemukan ialah siswa berjenis kelamin perempuan, berusia 17 tahun, memiliki riwayat keluarga inti dengan kelainan refraksi, dan melakukan aktivitas melihat jarak dekat dan lama ialah menonton televisi.

\section{DAFTAR PUSTAKA}

1. Kumasela GP, Saerang JSM, Rares LM. Hubungan waktu penggunaan laptop dengan keluhan penglihatan pada mahasiswa Fakultas Kedokteran Universitas Sam Ratulangi. J eBiomedik (eBM). 2013;1(1):291-9.

2. Ratanna RS, Rares LM, Saerang JSM. Kelainan refraksi pada anak di BLU RSU Prof. Dr. R. D. Kandou. eCl. 2014;2(2).

3. World Health Organization. Global data on visual impairments 2010. [cited 2015 Okt 13]. Available from: http://www.who.int/blindness/GLOBA
LDATAFINALforweb.pdf?ua=1

4. World Health Organization. Visual impairment and blindness. WHO; 2014. [cited 2015 Okt 13]. Available from: http://www.who.int/entity/ mediacentre/factsheets/fs282/en/index. html

5. Wong DL. Buku Ajar Keperawatan Pediatrik (6th ed). Jakarta: EGC, 2008.

6. Hutahuruk M. Hubungan antara pengetahuan dengan sikap orang tua tentang kelainan refraksi pada anak [Skripsi]. Semarang: FK Universitas Diponegoro; 2009.

7. Komariah C, Wahyu N. Hubungan status refraksi, dengan kebiasaan membaca, aktivitas di depan komputer, dan status refraksi orang tua pada anak usia Sekolah Dasar. Jurnal Kedokteran Brawijaya. 2014;28(2).

8. Czepita D, Mojsa A, Ustianowska M, Czepita M, Lachowicz E. Prevalence of refractive errors in school childern ranging from 6 to 18 years old. Ann Acd Med Stetin. 2007;53(1):53-6.

9. Usman S, Nukman E, Bebasari E. Hubungan antara faktor keturunan, aktivitas melihat dekat dan sikap pencegahan mahasiswa kedokteran universitas Riau terhadap kejadian Miopia. JOM FK. 2014;1(2).

10.Joseph N, Nelliyani M, dkk. Proportion of refractive error and its associated factors among high school students in South India. British Journal of Medicine \& Medical Research. 2015

11. Fachrian D, Rahayu AB, Nasen AP, Rerung NE, Pramesti M, Sari EA dkk. Prevalensi kelainan tajam pengelihatan pada pelajar SD "X" Jatinegara Jakarta Timur. Majalah Kedokteran Indo. 2009.

12.Juneti, Bebasari E, Nukman E. Gambaran faktor-faktor yang mempengaruhi gangguan tajam pengelihatan pada anak Sekolah Dasar kelas V dan kelas VI di SDN 017 Bukit Raya Pekanbaru Tahun 2014. JOM FK. 2015;2.

13.Tiharyo I, Gunawan W, Suhardjo. Pertambahan miopia pada anak Sekolah Dasar daerah perkotaan dan pedesaan di Daerah Istimewa Yogyakarta. J Oftalmologi Indonesia. 2008;6(2). 